\title{
HUBUNGAN TINGKAT DEPRESI DENGAN KEJADIAN INKONTINENSIA URINE PADA LANSIA DI PANTI SOSIAL TRESNA WERDHA BUDI SEJAHTERA BANJARBARU
}

\author{
Anita Agustina,Yuniarti, Dina Okhtiarini \\ Email: anitaagustina080887@gmail.com \\ Fakultas Keperawatan dan Ilmu Kesehatan Universitas Muhammadiyah \\ Banjarmasin \\ Jln. S. Parman. Kompleks RS Islam, Banjarmasin, Kalimantan Selatan 70114
}

\begin{abstract}
ABSTRAK
Seiring bertambahnya usia, penuaan tidak dapat dihindari dan setiap individu akan mengalami perubahan baik pada fisik maupun mentalnya. Dari data World Health Orgalenization (WHO) pravalensi global gangguan depresi pada lansia didapatkan sebanyak 61,6\%. Depresi merupakan masalah mental yang paling banyak ditemui pada lansia akibat proses penuaan. Dari sebagian kejadian depresi pada lansia salah satunya disebabkan oleh inkontinensia urine. Inkontinensia adalah pengeluaran urine tanpa disadari dalam jumlah dan frekuensi yang cukup, sehingga berakibat timbulnya masalah gangguan kesehatan. Penelitian ini bertujuan untuk mengetahui hubungan tingkat depresi dengan kejadian inkontinensia urine pada lansia di Panti Sosial Tresna Werdha Budi Sejahtera Banjarbaru. Metode dalam penelitian ini menggunakan desain analitik korelasi dengan pendekatan cross sectional. Teknik pengambilan sampel menggunakan proposive sampling dengan jumlah sampel sebanyak 46 orang. Instrumen penelitian yang digunakan adalah kuesioner. Uji statistik yang digunakan adalah spearman rho. Hasil penelitian didapatkan lansia yang tinggal di Panti Sosial Tresna Werdha Budi Sejahtera Banjarbaru sebagian besar mengalami tingkat depresi ringan sebanyak 17 orang $(37,0 \%)$ dan yang mengalami inkontinensia urine sebanyak 25 orang $(54,3 \%)$. Hasil uji statistik spearman rho menunjukkan p hitung $(0,004)<\alpha(0,05)$ dan nilai correlations coefficient 0.417. Dapat disimpulkan ada hubungan tingkat depresi dengan kejadian inkontinensia urine pada lansia di Panti Sosial Tresna Werdha Budi Sejahtera Banjarbaru.
\end{abstract}

Kata Kunci: depresi, inkontinensia urine, lansia

\begin{abstract}
As people age, aging cannot be avoided and every individual will undergo changes both physically and mentally. From the World Health Organization (WHO) data, the global prevalence of depressive disorders in the elderly is $61.6 \%$. Depression is the most common mental problem in the elderly due to the aging process. One of the causes of depression in the elderly is urinary incontinence. Incontinence is the involuntary discharge of urine in sufficient quantity and frequency, resulting in health problems. This study aims to determine the relationship between the level of depression and the incidence of urinary incontinence in the elderly at the Tresna Werdha Budi Sejahtera Social Institution Banjarbaru. The method in this study uses a correlation analytic design with aapproach cross sectional. The sampling technique used proposive sampling with
\end{abstract}


a total sample of 46 people. The research instrument used was a questionnaire. The statistical test used is Spearman Rho. The results showed that the elderly who lived in Tresna Werdha Budi Sejahtera Social Institution Banjarbaru mostly experienced mild depression as many as 17 people (37.0\%) and who experienced urinary incontinence as many as 25 people (54.3\%). The results of thestatistic test spearman rho show p count $(0.004)<(0.05)$ and the correlation coefficient is 0.417 . It can be concluded that there is a relationship between the level of depression and the incidence of urinary incontinence in the elderly at the Tresna Werdha Budi Sejahtera Social Institution Banjarbaru.

Keywords: depression, urinary incontinence, elderly 


\section{PENDAHULUAN}

Sebagian besar negara-negara di dunia mengalami banyak kemajuan di bidang kesehatan. Hal ini tentunya membawa dampak positif, dimana penduduk di dunia dapat mencapai harapan hidup yang lebih lama. Dampak kemajuan ilmu pengetahuan dan teknologi (IPTEK), terutama di bidang kedokteran, termasuk penemuan obat-obatan seperti antibiotika yang mampu melenyapkan berbagai penyakit infeksi, berhasil menurunkan angka kematian bayi dan anak, memperlambat kematian, memperbaiki gizi dan sanitasi sehingga kualitas dan umur harapan hidup meningkat. Akibatnya, jumlah penduduk lanjut usia semakin bertambah banyak, bahkan cenderung lebih cepat dan pesat (Nugroho, 2014).

Saat ini di seluruh dunia, jumlah lanjut usia diperkirakan lebih dari 629 juta jiwa (satu dari 10 berusia lebih dari 60 tahun), dan pada tahun 2025, lanjut usia akan mencapai 1,2 miliyar (Nugroho, 2014). Dari data proyeksi penduduk, diperkirakan tahun 2017 terdapat 23,66 juta jiwa penduduk lansia di Indonesia (9,03\%). Diprediksi jumlah penduduk lansia tahun 2020 (27,08 juta), tahun 2025 (33,69 juta), tahun 2030 (40,95 juta) dan tahun 2035 (48,19 juta) (Kemenkes RI, 2017).

Di provinsi Kalimantan Selatan jumlah penduduk pada tahun 2019 adalah 4.244.096 jiwa sedangkan pada tahun 2020 tercatat sebanyak 4.303.979 jiwa yang berarti terjadi pertambahan penduduk selama 1 tahun terakhir (BPS Kalsel, 2020). Angka pertumbuhan lansia di provinsi Kalsel yang berusia antara 45-49 tahun sebanyak 208.231 orang, yang berusia antara 65-69 tahun sebanyak 54.436 sedangkan yang berusia $>70$ tahun sebanyak 39.120 orang (BPS Kalsel, 2020). Fenomena ini jelas mendatangkan jumlah konsekuensi, antara lain timbulnya masalah fisik, mental, sosial, serta kebutuhan pelayanan kesehatan dan keperawatan, terutama kelainan degeneratif (Nugroho, 2014).

Perubahan tubuh terjadi sejak awal kehidupan hingga usia lanjut pada semua organ dan jaringan tubuh. Keadaan itu tampak pula pada perubahan sistem perkemihan atau sistem urinaria. Pada keadaan normal, sfingter akan mengalami pengeluaran urine dengan menutup kandung kemih dan salurannya. Pada saat yang sama, otot dinding kandung kemih akan berkontraksi dan mendorong urine keluar. Pada lansia terjadi penurunan fungsi otot-otot yang disebut sfingter (terletak di dasar kandung kemih dan dinding saluran kemih) sehingga mengakibatkan inkontinensia urine yang merupakan pengeluaran urine secara spontan yang mengakibatkan masalah gangguan kesehatan dan sosial (Agoes et al., 2013).

Data dari Asia Pasific Continence Advisor Board (APCAB), pravalensi inkontinensia urine pada perempuan Asia adalah 14,6\%, dimana sekitar 5,8\% berasal dari Indonesia dan pravalensi inkontinensia urine pada laki-laki Asia adalah 6,8\%, dimana sekitar 5\% berasal dari Indonesia. Sekitar 15-30\% individu yang mengalami inkontinensia urine diperkirakan berusia lebih dari 60 tahun (Agoes et al., 2013).

Masalah inkontinensia urine merupakan masalah yang sering terjadi pada lansia. Faktor penyebab terjadinya inkontinensia urine salah satunya adalah melemahnya otot dasar panggul yang menyangga kandung kemih, kontraksi abnormal pada kandung kemih, obat diuretik, obat penenang terlalu banyak, radang saluran kemih dan faktor psikologis seperti depresi (Untari, 2019).

Seiring bertambahnya usia, penuaan tidak dapat dihindari dan setiap individu akan mengalami perubahan baik pada fisik maupun mentalnya. Penyakit yang sering menyerang para lanjut usia bukan karena penuaan itu sendiri, tetapi dikarenakan adanya perubahan dalam komposisi tubuh dan penurunan fungsi organ. Kondisi tersebut dapat terjadi lebih cepat jika lansia mengalami gangguan psikologis berkepanjangan yang mempengaruhi kualitas hidup lansia (Dewi, 2014).

Depresi merupakan masalah mental yang paling banyak ditemui pada lansia akibat proses penuaan (Tjokroprawiro et al., 2015). Depresi adalah perasaan sedih, ketidakberdayaan dan pesimis yang dapat berupa serangan yang ditujukan kepada diri sendiri atau perasaan marah yang dalam (Nugroho, 2014). 
Dari data World Health Orgalenization (WHO) pravalensi global gangguan depresi pada lansia didapatkan sebanyak 61,6\% (Nugroho, 2014). Sekitar 50-75\% depresi terjadi pada lansia yang tinggal di institusi panti werdha dan 10-15\% depresi terjadi pada lansia yang tinggal bersama keluarga (Stanley \& Beare dalam Azizah, 2011).

Panti Sosial Tresna Werdha Budi Sejahtera Banjarbaru merupakan tempat penitipan lansia. Jumlah lansia yang tinggal di tempat tersebut pada bulan Februari 2021 sebanyak 100 orang dengan jumlah lansia laki-laki yaitu 48 orang dan jumlah lansia perempuan yaitu 52 orang. Berdasarkan studi pendahuluan yang dilakukan peneliti pada tanggal 11 Februari 2021 di Panti Sosial Tresna Werdha Budi Sejahtera Banjarbaru diperoleh data yaitu dari 10 lansia diantaranya 5 orang lansia laki-laki dan 5 orang lansia wanita, terdapat 2 orang lansia laki-laki dan 3 orang lansia wanita yang mengalami depresi. Tiga orang lansia wanita dan dua orang lansia laki-laki yang mengalami depresi tersebut juga mengalami inkontinensia urine.

\section{METODE PENELITIAN}

Metode dalam penelitian ini menggunakan desain analitik korelasi dengan pendekatan cross sectional. Populasi dalam penelitian ini adalah seluruh lansia penghuni Panti Sosial Tresna Werdha Budi Sejahtera Banjarbaru tahun 2021 sebanyak 100 orang. Teknik pengambilan sampel dalam penelitian ini menggunakan proposive sampling dengan jumlah sampel sebanyak 46 orang. Instrumen penelitian yang digunakan adalah kuesioner. Penelitian ini telah dilaksanakan di Panti Sosial Tresna Werdha Budi Sejahtera Banjarbaru. Waktu penelitian dilakukan pada tanggal 19 - 23 Mei 2021. Variabel independen pada penelitian ini adalah tingkat depresi dan variabel dependen pada penelitian ini adalah inkontinensia urine.

\section{HASIL PENELITIAN}

Hasil yang didapatkan dalam penelitian ini dikategorikan dalam bentuk tabel distribusi frekuensi sebagai berikut:

\begin{tabular}{|c|c|c|c|}
\hline No & $\begin{array}{c}\text { Jenis } \\
\text { Kelamin }\end{array}$ & Frekuensi & $\begin{array}{c}\text { Persentase } \\
(\%)\end{array}$ \\
\hline 1 & Laki-laki & 23 & 50,0 \\
\hline 2 & Perempuan & 23 & 50,0 \\
\hline \multicolumn{2}{|c|}{ Total } & 46 & 100,0 \\
\hline
\end{tabular}

Tabel 4.2 Jumlah Responden Berdasarkan Jenis Kelamin

Hasil tabel 4.2 menunjukkan responden yang berjenis kelamin laki-laki yaitu sebanyak 23 orang $(50,0 \%)$ dan perempuan sebanyak 23 orang $(50,0 \%)$.

\begin{tabular}{|c|c|c|c|}
\hline No & Usia & Frekuensi & Persentase (\%) \\
\hline 1 & $60-74$ & 31 & 67,4 \\
\hline 2 & $75-90$ & 15 & 32,56 \\
\hline
\end{tabular}




\begin{tabular}{|l|l|l|}
\hline Total & 46 & 100,0 \\
\hline
\end{tabular}

Tabel 4.3 Jumlah Responden Berdasarkan Usia

Hasil tabel 4.3 menunjukkan bahwa sebagian besar responden berusia 60-74 tahun yaitu sebanyak 31 orang $(67,3 \%)$.

\begin{tabular}{|c|l|c|c|}
\hline No & Tingkat Depresi & $\begin{array}{c}\text { Frekue } \\
\text { nsi }\end{array}$ & $\begin{array}{c}\text { Persentase } \\
(\%)\end{array}$ \\
\hline 1 & Tidak Depresi & 29 & 63,0 \\
\hline 2 & Depresi Ringan & 17 & 37,0 \\
\hline 3 & $\begin{array}{l}\text { Depresi } \\
\text { Sedang/Berat }\end{array}$ & 0 & 0 \\
\hline \multicolumn{2}{|c|}{ Total } & 46 & 100,0 \\
\hline
\end{tabular}

Tabel 4.4

Distribusi Frekuensi Responden Berdasarkan Tingkat Depresi di Panti Sosial Tresna Werdha Budi Sejahtera Banjarbaru

Hasil tabel 4.4 menunjukkan bahwa sebagian besar tingkat depresi pada kategori tidak depresi yaitu sebanyak 29 orang $(63,3 \%)$.

\begin{tabular}{|c|l|c|c|}
\hline $\begin{array}{c}\mathrm{N} \\
\mathrm{o}\end{array}$ & \multicolumn{1}{|c|}{ Inkontinensia Urine } & $\begin{array}{c}\text { Frekuens } \\
\mathrm{i}\end{array}$ & $\begin{array}{c}\text { Persenta } \\
\text { se (\%) }\end{array}$ \\
\hline 1 & $\begin{array}{l}\text { Tidak Inkontinensia } \\
\text { Urine }\end{array}$ & 0 & 0 \\
\hline 2 & Inkontinensia Ringan & 20 & 43,5 \\
\hline 3 & $\begin{array}{l}\text { Inkontinensia } \\
\text { Sedang }\end{array}$ & 25 & 54,3 \\
\hline 4 & $\begin{array}{l}\text { Inkontinensia Berat } \\
\text { Total }\end{array}$ & 46 & 100,0 \\
\hline
\end{tabular}

Tabel 4.5 Distribusi Frekuensi Responden Berdasarkan Kejadian Inkontinensia Urine di Panti Sosial Tresna Werdha Budi Sejahtera Banjarbaru.

Hasil tabel 4.5 menunjukkan bahwa sebagian besar kejadian inkontinensia urine pada kategori inkontinensia sedang yaitu sebanyak 25 orang $(54,3 \%)$.

\section{Inkontinensia Urine}




\begin{tabular}{|c|c|c|c|c|c|c|c|c|c|c|}
\hline \multirow[t]{2}{*}{$\begin{array}{l}\text { Tingkat } \\
\text { Depresi }\end{array}$} & \multicolumn{2}{|c|}{$\begin{array}{c}\text { Tidak } \\
\text { inkonti } \\
\text { nensia }\end{array}$} & \multicolumn{2}{|c|}{$\begin{array}{c}\text { Inkonti } \\
\text { nensia } \\
\text { ringan }\end{array}$} & \multicolumn{2}{|c|}{$\begin{array}{l}\text { Inkonti } \\
\text { nensia } \\
\text { sedang }\end{array}$} & \multicolumn{2}{|c|}{$\begin{array}{c}\text { Inkontin } \\
\text { ensia } \\
\text { berat }\end{array}$} & \multirow{2}{*}{\multicolumn{2}{|c|}{ Total }} \\
\hline & $\mathrm{F}$ & $\%$ & $\mathrm{~F}$ & $\%$ & $\mathrm{~F}$ & $\%$ & $\mathrm{~F}$ & $\%$ & & \\
\hline Tidak depresi & 0 & 0,0 & $\begin{array}{l}1 \\
7\end{array}$ & $\begin{array}{c}58, \\
6\end{array}$ & $\begin{array}{l}1 \\
2\end{array}$ & $\begin{array}{c}41 \\
4\end{array}$ & 0 & 0,0 & 29 & $\begin{array}{l}10 \\
0,0\end{array}$ \\
\hline $\begin{array}{l}\text { Depresi } \\
\text { ringan }\end{array}$ & 0 & 0,0 & 3 & $\begin{array}{c}17 \\
6\end{array}$ & $\begin{array}{l}1 \\
3\end{array}$ & $\begin{array}{c}76 \\
5\end{array}$ & 1 & 5,9 & 17 & $\begin{array}{l}10 \\
0,0\end{array}$ \\
\hline $\begin{array}{l}\text { Depresi } \\
\text { sedang/ berat }\end{array}$ & 0 & 0,0 & 0 & 0,0 & 0 & 0,0 & 0 & 0,0 & 0 & 0,0 \\
\hline Total & 0 & 0,0 & $\begin{array}{l}2 \\
0\end{array}$ & $\begin{array}{c}43 \\
5\end{array}$ & $\begin{array}{l}2 \\
5\end{array}$ & $\begin{array}{c}54, \\
3\end{array}$ & 1 & 2,2 & 46 & $\begin{array}{l}10 \\
0,0\end{array}$ \\
\hline & & & & 0,4 & & & & & & \\
\hline
\end{tabular}

Sejahtera Banjarbaru
Tabel 4.6 Tabulasi Silang Tingkat Depresi dengan Kejadian Inkontinensia Urine pada Lansia di Panti Sosial Tresna Werdha Budi

Hasil tabel 4.6 menunjukkan bahwa dari 46 responden 29 orang responden yang tidak depresi, sebanyak 17 orang $(58,6 \%)$ mengalami inkontinensia ringan dan 12 orang $(41,4 \%)$ mengalami inkontinensia sedang, kemudian dari 17 orang responden yang mengalami depresi ringan sebanyak 3 orang $(17,6 \%)$ mengalami inkontinensia ringan, 13 orang $(76,5 \%)$ mengalami inkontinensia sedang dan 1 orang $(5,9 \%)$ mengalami inkontinensia berat. Namun tidak ada satu orang responden pun $(0 \%)$ mengalami depresi sedang atau berat yang mengalami inkontinensia urine.

\section{PENELITIAN DAN HASIL PEMBAHASAN}

Hasil penelitian menunjukkan bahwa lansia yang berada di Panti Sosial Tresna Werdha Budi Sejahtera Banjarbaru Tahun 2021 yang berjumlah 46 responden, sebagian besar lansia mengalami inkontinensia sedang sebanyak 25 responden $(54,3 \%)$. Hasil penelitian ini didukung oleh Amelia (2020) yang menemukan bahwa lansia di Panti Sosial Tuna Wedha Sumatra Barat banyak mengalami inkontinensia sedang sebesar $85,71 \%$ karena semakin lanjut usia seseorang semakin berisiko untuk mengalami inkontinensia urine, karena faktor penurunan efisiensi dan fungsi organ secara fisiologis akibat proses penuaan. Penelitian ini juga sejalan dengan penelitian yang dilakukan oleh Chesor (2015) menemukan bahwa yang terbanyak adalah inkontinensia urine sedang sebesar 34,9\%.

Teori Sunarti (2019) menjelaskan bahwa pada lanjut usia baik wanita maupun pria terjadi perubahan anatomis dan fisiologis dari sistem urogenital bagian bawah. Perubahan tersebut berkaitan dengan menurunnya kadar estrogen pada wanita dan hormon androgen pada pria. Perubahan yang terjadi dapat berupa peningkatan fibrosis dan kandungan kolagen pada dinding kandung kemih yang mengakibatkan fungsi kontraktil dari kandung kemih tidak efektif lagi. Pada otot uretra terjadi perubahan vaskularisasi pada lapisan submukosa, atrofi mukosa, dan penipisan otot uretra. Keadaan ini menyebabkan tekanan penutupan uretra berkurang. Otot dasar panggul juga mengalami perubahan berupa melemahnya fungsi dan kekuatan otot. Secara keseluruhan perubahan yang terjadi pada sistem urogenital bagian bawah akibat proses menua merupakan faktor kontributor terjadinya inkontinensia urine. 
Diketahui juga pada hasil penelitian yang didapatkan bahwa lansia mengalami frekuensi buang air kecil yang sering, frekuensi buang air kecil yang sering ini dikarenakan faktor penurunan fungsi tubuhnya yang menyebabkan pengeluaran urine yang tidak terkontrol. Pengeluaran urine yang tidak terkontrol ini membuat lansia merasa ingin buang air kecil terus menerus apalagi paling sering terbangun pada malam hari untuk buang air kecil. Hal ini juga dipengaruhi oleh beberapa faktor yaitu jenis minuman yang dikonsumsi lansia, penyakit yang diderita, serta jarak antara kamar mandi/toilet yang jauh. Selain itu dapat kita ketahui juga bahwa inkontinensia urine yang sering terjadi ini ditemukan pada lanjut usia karena terjadinya penurunan fungsi tubuh. Inkontinensia urine tipe urgensi merupakan kasus tersering yang terjadi pada lansia. Lanjut usia di panti werdha banyak ditemukan juga mengalami inkontinensia tipe urgensi, inkontinensia tipe ini merupakan inkontinensia akibat ketidakmampuan untuk menunda kemih dimana lansia merasa sensasi untuk berkemihnya muncul, tetapi jumlah urine sedikit dan frekuensi berkemihnya sering. Lanjut usia biasanya mengeluh bahwa tidak punya cukup waktu untuk menahan keluarnya urine sampai ke kloset atau ke tempat yang layak untuk berkemih. Pada tanda gejala urgensi tersebut sering kali ditemukan dan dialami oleh lansia.

Dari hasil penelitian juga ditemukan lansia yang berada di Panti Sosial Tresna Werdha Budi Sejahtera Banjarbaru yang mengalami inkontinensia berat sebanyak 1 responden $(2,2 \%)$. Hasil penelitian ini juga didukung oleh Wisti (2019) yang menemukan bahwa lansia paling banyak mengalami inkontinensia urine kategori parah yaitu terdapat (41,54\%), yang menyatakan bahwa lansia mengalami penurunan fungsi tubuh sehingga terjadinya inkontinensia urine.

Menurut teori oleh Cameron (2013) bahwa inkontinensia urine adalah salah satu masalah umum pada pria maupun wanita lanjut usia yang merupakan pengeluaran urine yang tak terkendali dan dapat menyebabkan masalah fisik, emosional, sosial pada penderita. Hal ini sesuai dengan teori yang mengatakan bahwa inkontinensia urine adalah masalah dan gangguan umum di antara pasien geriatri dan diperkirakan bahwa $25-35 \%$ dari seluruh orang tua akan mengalami inkontinensia urine selama kejadian seumur hidup (Onat, 2014).

Dari hasil penelitian tersebut didapatkan lansia yang berada di Panti Werdha mengalami inkontinensia berat karena salah faktor utamanya yaitu penurunan fungsi tubuh pada lansia tersebut. Usia juga memengaruhi terjadinya penurunan sistem perkemihan pada lansia, karena semakin usianya tua maka fungsi pada tubuhnya tidak bekerja dengan maksimal seperti dulu, sehingga lansia mengalami inkontinensia yang berat. Adapun faktor lain lansia yang mengalami inkontinensia berat yaitu lansia yang mengonsumsi obat deuretik yang mengakibatkan sering berkemih. Maka dari itu diperlukan latihan fisik seperti latihan kagel agar lansia bisa mengontrol sistem perkemihannya dan inkontinensia menurun tidak ke tahap yang lebih berat lagi.

Hasil penelitian ini juga mengemukakan bahwa inkontinensia urine yang terjadi banyak dialami oleh lansia berusia 60-74 tahun dan usia 75-90 tahun. Penelitian ini juga didukung oleh Amelia (2020) bahwa jumlah lansia terbanyak berdasarkan kategori usia yang mengalami inkontinensia urine adalah $65-75$ tahun $(50,85 \%)$. Hasil penelitian ini juga serupa dengan penelitian yang dilakukan oleh Wilson, et al (2017) bahwa lansia yang mengalami inkontinensia urine terbanyak pada rentang usia 71-80 tahun. Semakin seseorang itu tua atau lanjut usia, semakin beresiko juga untuk mengalami inkontinensia urine, karena faktor penurunan efisiensi dan fungsi organ secara fisiologis akibat proses penuaan.

Pada hasil penelitian yang didapat bahwa lansia yang mengalami inkontinensia urine sebagian besar lansia perempuan dan laki-laki yang berusia 75-90 tahun mengalami inkontinensia ringan dan sedang, usia yang mempengaruhi penurunan fungsi tubuh karena usia yang lebih tua itu menurunnya kesehatan para lansia. Hasil penelitian menunjukkan bahwa lansia yang berada di Panti Sosial Tresna Werdha Budi Sejahtera Banjarbaru Tahun 
2021 yang berjumlah 46 responden, didapatkan 17 responden $(37,0 \%)$ mengalami depresi ringan.

Hasil ini didukung juga oleh penelitian Wisti, et al (2019) menemukan depresi lansia di Panti Werdha Dharma Bhakti Pajang Surakarta paling banyak mengalami depresi ringan yaitu sebesar 35,38\%. Sejalan dengan penelitian oleh Parulian Gulton, et al (2016) yang menyatakan bahwa kategori depresi ringan lebih banyak dibandingkan dengan depresi berat diakibatkan juga karena pengaruh lingkungan atau kebiasaan baik seperti sering berbagi masalah antara satu lansia dengan lansia lain serta aktif dalam kegiatan yang dijalankan di panti. Hasil penelitian ini serupa oleh Wilson, et al (2017) menyatakan bahwa lansia yang tinggal di PSTW lebih cenderung mengalami depresi ringan dibandingkan lansia yang tinggal ditengah keluarga yang cenderung tidak depresi.

Seperti yang kita ketahui bahwa pada lansia lebih sering terjadi mengalami depresi dibandingkan pada populasi umum. Menurut teori, depresi merupakan masalah mental yang paling banyak ditemui pada lansia akibat proses penuaan (Tjokroprawiro et al., 2015). Lansia yang berada di panti memiliki tingkat depresi yang lebih tinggi daripada lansia yang berada dirumah (Pae, 2017).

Depresi adalah masalah medis yang serius dengan melibatkan gejala-gejala yang berkaitan dengan mood, kognitif dan gejala fisik. Gejala-gejala yang berkaitan dengan mood yaitu depresi, sedih, kehilangan minat pada aktivitas sehari-hari, ketidakmampuan untuk merasakan kesenangan, merasa bersalah, tidak berguna dan pikiran tentang kematian serta ide bunuh diri. Gejala kognitif termasuk ketidakmampuan untuk berkonsentrasi dan kesulitan dalam membuat keputusan. Kelelahan, kekurangan energi, gerak melambat dan perubahan pada pola tidur, nafsu makan dan tingkat aktivitas merupakan gejala fisik yang terlihat pada pasien depresi (Pratt \& Brody, 2014).

Soejono (2012) mengungkapkan bahwa depresi merupakan gangguan psikiatri yang paling sering terjadi pada lansia, hal ini terjadi akibat dari interaksi faktor biologi, fisik, psikologis, dan sosial. Pada faktor sosial penyebab depresi pada usia lanjut disebabkan adanya isolasi sosial, kehilangan kerabat dekat, kehilangan pekerjaan dari kegiatan harian, serta kehilangan pendapat. Faktor luar yang dapat mempengaruhi terjadinya depresi adalah kurangnya social support, dukungan keluarga, lingkungan dan tersedianya komunitas lansia (Ibrahim, 2011).

Depresi adalah suatu keadaan emosional yang ditandai dengan kehilangan minat dan kegembiraan terhadap hal yang menyenangkan serta merasakan kesedihan yang mendalam, perasaan tidak berharga, merasa bersalah dan menarik diri dari orang lain dilingkungannya (Muhith \& Nazir, 2011). Menurut Pedoman dan Penggolongan Diagnosis Gangguan Jiwa (PPDGJ)-III, gejala depresi ringan yakni kehilangan minat dan kegembiraan, berkurangnya energi yang menuju meningkatnya keadaan mudah lelah dan menurunnya aktivitas, konsentrasi dan perhatian yang kurang dan harga diri dan kepercayaan diri yang kurang. Depresi merupakan penyakit mental yang paling sering pada pasien berusia di atas 60 tahun dan merupakan contoh penyakit yang paling umum dengan tampilan gejala yang tidak spesifik/ tidak khas pada lansia (Pae, 2017).

Dari data penelitian yang didapatkan, dapat kita ketahui bersama usia lansia yang berkisar antara 60-74 tahun itu akan mengalami banyak dampak negatif atau banyak terjadi sesuatu yang buruk pada lansia tersebut salah satunya terjadinya depresi, apalagi lansia yang baru saja masuk ke dalam panti itu akan rentan mengalami depresi. Pada penelitian didapatkan bahwa lansia yang baru saja masuk ke dalam panti werdha sekitar beberapa bulan yang lalu, lansia tersebut masih merasa asing, tidak bisa menerima dirinya karena dimasukkan ke dalam panti dan lansia tersebut tidak bisa bersosialisasi dengan teman sebayanya sehingga muncul depresi pada lansia.

Penelitian ini mengungkapkan bahwa sebagian besar lansia yang berada di panti werdha sebagian besar mengalami depresi ringan karena lansia mengalami tekanan dalam 
kehidupannya yang merasakan adanya ketidakmampuan diri yang berkurang serta adanya rasa kesepian karena berkurangnya peran yang dirasakan oleh lansia tersebut. Adanya perasaan gelisah, kemudian keaadaan yang tidak sesuai harapan membuat lansia merasa khawatir tentang sesuatu hal yang buruk akan terjadi pada dirinya. Kemudian, keterbatasan fisik yang dimiliki lansia menjadi pemicu timbulnya tingkat depresi. Lansia yang memiliki keterbatasan fisik yang besar tidak dapat melakukan aktivitas sehari-hari secara mandiri cenderung menjadi depresi. Aktivitas sehari-hari yang tidak bisa dilakukan lansia seperti tidak sanggup dalam melakukan pekerjaan rumah seperti menyuci piring ketika habis makan, membereskan tempat tidur, menyapu, berjalan dan ketika beribadah menjadi terganggu karena merasakan sakit pada sendi, dengan keadaannya dan lingkungan disekitar tidak menerima keadaan lansia tersebut.

Kondisi lain yang menjadi alasan lansia lebih banyak menderita depresi adalah terlihat dari alasan lansia tersebut masuk ke panti. Sebagian besar lansia masuk ke dalam panti karena dikirim oleh masyarakat, dikirim oleh keluarga dan keinginannya sendiri untuk masuk panti. Seseorang yang tidak memiliki motivasi, cenderung untuk tidak melakukan sesuatu di luar keinginannya. Lansia yang tidak punya motivasi untuk tinggal dan melakukan kegiatan di panti, menghabiskan waktunya dengan tidak bersemangat. Kurangnya aktivitas ini, mendorong perasaan kosong, kebosanan dan kehampaan yang dapat berujung pada depresi pada lansia.

Sebagian besar lansia dikunjungi oleh keluarganya dan sebagian lansia tidak punya keluarga karena ada lansia yang terlantar tidak punya sama sekali keluarga. Dalam sebulan ada beberapa kali kunjungan oleh keluarga lansia. Kunjungan itu membuat rasa rindu lansia kepada keluarga terobati.

Selain itu, dari hasil penelitian tersebut dapat dilihat juga bahwa mayoritas responden di Panti Sosial Tresna Budi Sejahtera Banjarbaru sebagian besar tidak mengalami depresi sebanyak 29 responden. Hasil ini didukung oleh penelitian Made, et al (2019) di Panti Sosial Tresna Werda Wana Seraya Denpasar ditemukan juga sebanyak 39,1\% lansia yang tidak mengalami depresi karena produktivitas fisik lansia masih baik dan bisa menjaga kesehatannya dengan baik.

Darmojo (2015) mengungkapkan bahwa lansia yang dapat menghadapi perubahan dengan tetap bisa menjalin komunikasi dengan orang lain akan mudah menghadapi perubahan dengan lebih positif dan dapat mengisi masa tuanya dengan optimal. Selain itu, lansia yang tinggal di panti memiliki interaksi sosial yang baik dan sebagian besar di antaranya tidak mengalami depresi. Ini berarti bahwa interaksi sosial yang terjalin baik diantara penghuni panti mampu menekan tingkat depresi yang dialami lansia.

Hasil penelitian ini diketahui bahwa seorang lansia yang dapat menjalankan kehidupannya dengan baik maka terlihat bahwa dirinya sudah puas dengan kehidupannya ditandai dengan dia mampu melakukan aktivitasnya dengan baik tanpa masalah yang menggangu baik dari dirinya maupun dari lingkungannya, melakukan kegiatan-kegiatan yang positif yang dapat membuatnya bahagia dan tidak merasakan adanya ketegangan dalam menjalankan hidup yang membuatnya merasa depresi atau tertekan. Interaksi sosial yang baik pada lansia membuat lingkungan disekitarnya menerima keadaan diri lansia sehingga tidak berdampak terjadinya depresi. Lansia yang berteman dengan baik dengan teman sebayanya akan membuat lansia tidak merasa kesepian.

Berdasarkan hasil penelitian tersebut didapatkan bahwa tingkat depresi cenderung berpengaruh dengan inkontinensia urine karena berdasarkan analisis uji statistik ternyata di Panti Sosial Tresna Werdha Budi Sejahtera Banjarabaru menunjukkan bahwa dari total 46 respnden terdapat 17 orang yang depresi ringan. Dari 17 orang yang mengalami depresi sebanyak 3 orang $(17,6 \%)$ mengalami inkontinensia ringan, 13 orang $(76,5 \%)$ mengalami inkontinensia sedang dan 1 orang $(5,9 \%)$ mengalami inkontinensia berat.

Dari hasil uji statistik spearman rank antara hubungan tingkat depresi dengan kejadian inkontinensia urine dapat dilihat bahwa hasil menunjukkan nilai $\mathrm{p}$ value 0,004 yaitu di bawah 
nilai alpha 0,05 yang berarti ada hubungan tingkat depresi dengan kejadian inkontinensia urine pada lansia di Panti Sosial Tresna Werdha Budi Sejahtera Banjarbaru. Dengan nilai correlations coefficient $=0,417$ sehingga dapat disimpulkan bahwa Ho ditolak dan $\mathrm{Ha}$ diterima.

Hasil penelitian ini sejalan dengan Astari (2020) yang menyatakan ada hubungan tingkat depresi terhadap kualitas hidup pada lansia dengan inkontinensia urine. Hasil penelitian menunjukkan bahwa mayoritas lansia mengalami tingkat depresi berat dan kualitas hidup tidak baik sehingga dapat disimpulkan bahwa ada hubungan antara tingkat depresi dengan kualitas hidup pada lansia. Lansia yang mengalami tingkat depresi berat memiliki risiko yang tinggi terhadap penurunan kualitas hidup dan masalah kesehatan salah satu yang sering terjadi adalah inkontinensia urine.

Depresi merupakan masalah mental yang banyak dialami oleh lansia dan gangguan ini jarang terdeteksi karena sering dianggap sebagai konsekuensi dari proses menua (Dewi, 2014). Depresi yang berkepanjangan dapat mengakibatkan terjadinya penurunan fungsi organ pada lansia salah satu dampaknya yaitu penurunan pada fungsi sistem urinaria yang sering terjadi pada lansia adalah inkontinensia urine.

Pada lansia terjadi inkontinensia urine yang merupakan pengeluaran urine secara spontan yang mengakibatkan masalah gangguan kesehatan dan sosial (Agoes, 2013). Teori Untari (2019) meyatakan bahwa faktor penyebab terjadinya inkontinensia urine salah satunya melemahnya otot dasar panggul yang menyangga kandung kemih, kontraksi abnormal pada kandung kemih, obat diuretik dan faktor psikologis seperti depresi.

Inkontinensia urine mempunyai pengaruh terhadap kondisi psikologis lansia. Inkontinensia urine dapat menyebabkan terganggunya aktivitas lansia sehari-hari. Akibatnya akan terjadi isolasi sosial (Aslam \& Mahreen, 2018). Inkontinensia urine juga dapat menyebabkan perasaan malu sehingga individu dengan inkontinensia urine akan membatasi bahkan menghindari kontak sosial dengan lingkungannya yang nantinya akan menyebabkan isolasi sosial pada lansia. Isolasi sosial yang terjadi dapat menyebabkan gangguan psikologis pada lansia yaitu depresi (Sticklet et al., 2017).

Hasil penelitian yang didapat bahwa lansia itu masing-masing memiliki setiap masalah. Pada lansia yang mengalami depresi akan menimbulkan akibat yang berbeda-beda karena usia yang sudah tua akan mudah terkena berbagai penyakit, salah satunya adalah inkontinensia urine. Selain itu juga, diketahui bahwa lansia itu dapat mengalami depresi dan juga tidak mengalami depresi. Biasanya depresi yang didapatkan pada lansia berupa depresi ringan, sedang sampai ke depresi berat. Masalah yang dialami seperti depresi ini dapat mengakibatkan berbagai masalah lain yang muncul dalam diri lansia itu sendiri. Salah satunya masalah perubahan fungsi tubuh dan masalah psikososial yang bisa menyebabkan terjadinya inkontinensia urine pada lansia.

Seiring bertambahnya usia terjadi perubahan biologis atau penurunan fungsi tubuh dan perubahan psikososial pada lansia, salah satu perubahan yang terjadi pada penurunan fungsi tubuh yaitu terjadinya inkontinensia urine. Inkontinensia urine ini terjadi tanpa dikehendaki oleh lansia dan bisa terjadi dimanapun tanpa disadari oleh mereka, baik saat duduk dengan teman atau sedang sendiri sehingga saat inkontinensia itu terjadi lansia tidak mampu berbuat apa-apa untuk mengontrol buang air kecil, sehingga lansia akan merasa malu atau takut untuk berkumpul dengan teman-temannya apalagi sampai teman-temannya tau lansia itu mengalami inkontinensia urine. Karena hal itu, stres yang dialami lansia itu semakin banyak sehingga lansia membutuhkan adaptasi biologis, salah satu adaptasi biologis yaitu mengatasi tekanan dilingkungan sekitarnya. Serta lansia kurang dapat menikmati kehidupan sehari-hari yang bisa menyebabkan depresi.

Selain itu juga, depresi yang dialami oleh lansia akan menyebabkan hilangnya kepercayaan diri dari masing-masing lansia itu, karena pengaruh dari luar atau dari lingkungan yang tidak sesuai untuk menerima keadaan dirinya. Upaya yang dilakukan dalam menangani 
masalah depresi sebaiknya dilakukan oleh pihak panti yaitu lebih memperhatikan apa yang dibutuhkan oleh lansia, memotivasi lansia untuk mengikuti semua kegiatan yang diadakan oleh panti seperti bimbingan keagamaan, mendorong lansia untuk tidak berdiam diri di kamar saja dengan cara bersosialisasi dengan lansia lain, menikmati pemandangan yang ada disekitar dan melakukan kegiatan secara mandiri.

\section{KESIMPULAN}

1. Sebagian besar lansia yang mengalami tingkat depresi di Panti Sosial Tresna Werdha Budi Sejahtera Banjarbaru tahun 2021 sebanyak 17 orang responden $(37,0 \%)$ yang mengalami depresi ringan.

2. Sebagian besar lansia yang mengalami inkontinensia urine di Panti Sosial Tresna Werdha Budi Sejahtera Banjarbaru tahun 2021 sebanyak 25 orang responden (54,3\%) yang mengalami inkontinensia sedang.

3. Ada hubungan tingkat depresi dengan kejadian inkontinensia urine pada lansia di Panti Sosial Tresna Werdha Budi Sejahtera Banjarbaru tahun 2021 dengan hasil Uji SpearmanRho pvalue $=0,004<\alpha=0,05$ dan $r=0,417$.

\section{DAFTAR PUSTAKA}

Agoes, A., Agoes, A., \& Agoes, A. (2013). Penyakit Usia Tua. Jakarta: EGC.

Amelia, R. (2020). Prevalensi dan Faktor Risiko Inkontinensia Urin pada lansia di Panti Sosial Tuna Werdha (PSTW) Sabai Nan Aluih Sicincin Pariaman. Health \& Medical Journal, 2(1), 39-44.

Aslam, N., \& Mahreen, K. (2018). Role of Urinary Incontinence in Depression and Life Satisfaction in Geriatric Patients. Pakistas Journal of Public Health, 8 (4), 185-189.

Astari, Febri. (2020). Hubungan Tingkat Depresi Terhadap Kualitas Hidup Pada Lansia Dengan Inkontinensia Urine. Program Studi Ilmu Keperawatan Fakultas Ilmu Keperawatan Universitas Islam Sultan Agung Semarang.

Azizah, L. M. (2011). Keperawatan Lanjut Usia. Yogyakarta: Graha Ilmu.

BPS Provinsi Kalsel. 2018. Jumlah Penduduk Kalimantan Selatan Menurut Umur dan Jenis Kelamin. Termuat dalam: https://kalsel.bps.go.id/statictable/2016/10/10/690/jumlah-penduduk kalimantanselatan-menurut-kelompok-umur-dan jenis-kelamin-2010-hasil-sp2010-angkafinal-.html (diakses pada tanggal 22 Desember 2020)

BPS Provinsi Kalsel. 2020. Proyeksi Penduduk Menurut Kabupaten/Kota Dan Jenis Kelamin Tahun 2010-2020. Termuat dalam:file://C:/Users/User/Downloads/48741-IDproyeksi-penduduk-kabupatenkota-provinsi-kalimantan-selatan-2010 2020.pdf (diakses pada tanggal 22 Desember 2020).

Cameron A, Joel J, Heidelbaugh \& Masahito Jimbo (2013). Diagnosis and Office Based Treatoment of Urinary Incontinence in Adults. Therapeutic Advances in Urology, 5, 181-187.

Chesor, A. (2015). Hubungan Antara Inkontinensia Urine Dengan Depresi Pada Lanjut Usia Di Panti Werda Dharma Bakti Pajang Surakarta. Jurnal Keperawatan, 1-14.

Darmojo, Boedhi. (2015). Buku Ajar Geriatri (Ilmu Kesehatan Usia Lanjut). Jakarta: FKUI. Dewi, S. R. (2014). Buku Ajar Keperawatan Gerontik. Yogyakarta: Deepublish. Ibrahim, A. S. (2011). Gangguan Alam Perasaan. Tanggerang: Jelajah Nusa.

Kemenkes RI. (2017). Analisis Lansia di Indonesia. Pusat Data Dan Informasi Kementerian Kesehatan RI, 1-2. Termuat dalam: http://www.depkes.go.id (diakses pada tanggal 22 Januari 2021).

Made, Desak S., C., S., Putrawan, I. B., \& Rai, N. K. (2019). Hubungan Tingkat Inkontinensia Urine Dengan Derajat Depresi Pada Pasien Lanjut Usia di Panti Sosial Tresna Werdha Wana Seraya Denpasar. Jurnal Medika Udayana. 8(8). 
Muhith \& Nasir. (2011). Dasar-dasar Keperawatan Jiwa. Pengantar dan Teori. Jakarta: Salemba Medika.

Nugroho, W. (2014). Keperawatan Gerontik \& Geriatrik (Edisi 3). Jakarta: EGC.

Onat, S. (2014). Relationship between urinary incontinence and quality of lif/depression in elderly patients. Journal of Clinical Gerontology \& Geriatrics, 5, 86-90.

Pae, K. (2017). Perbedaan Tingkat Depresi Pada Lansia Yang Tinggal Di Panti Werdha Dan Yang Tinggal Di Rumah Bersama Keluarga. Jurnal Ners LANTERA, 5(1).

Parulian Gultom,. Hnedro Bidjuni., Vendri Kallo. (2016). Hubungan Aktivitas Spiritual Dengan Tingkat Depresi Pada Lansia Di Balai Penyantunan Lanjut Usia Senja Cerah Kota Manado. e-journal Keperawatan, 4 (2).

Pratt, L. A., \& Brody, D. J. (2014). Depression and Obesity in The U.S. Adult Household Population. US National Library of Medicine National Institutes of Health, 1-8.

PSTW Budi Sejahtera (2013). Profil Panti Sosial Tresna Werdha Budi Sejahtera Prov Kalsel. Termuat dalam: pstwbudisejahtera.wordpress.com. (diakses pada tanggal $17 \mathrm{Mei}$ 2021)

Soejono, C. H. (2012). Pedoman Pengelolaan Kesehatan Pasien Geriatrik Untuk Dokter \& Perawat. Jakarta: FK UI.

Sunarti, S., Ratnawati, R., Nugrahenny, D., Mattalitti, G. N. M., Ramadhan, R., Budianto, R., Pratiwi, I. C., \& Prakosa, A. G. (2019). Prinsip Dasar Kesehatan Lanjut Usia (Geriatrik). Malang: UB Press.

Stickley, A., Santini, Z. I., \& Koyanagi, A. (2017). Urinary Incontinence, mental health and loneliness among community-dwelling older adults in Ireland. BioMed Central Urology, 17 (29), 1-9.

Tjokroprawiro, A., Setiawan, P. B., Santoso, D., Soegiarto, G., \& Rahmawati, L. D. (2015). Buku Ajar Ilmu Penyakit Dalam (Edisi 2). Surabaya: Airlangga University Press.

Untari, I. (2019). Buku Ajar Keperawatan Gerontik Terapi Tertawa \& Senam Cegah Pikun. Jakarta: EGC.

Wilson, A., Kundre, R., \& Onibala, F. (2017). Hubungan Inkontinensia Urin Dengan Tingkat Depresi Pada Lansia Di Panti Werdha Bethania Lembean. Jurnal Keperawatan UNSRAT, 5(1).

Wisti, Widiyono, \& Aryani, A. (2019). The Correlation Of Inconsistency Urine To Depression On Elderly In Werdha Dharma Bhakti Nursing Home Of Pajang Surakarta. Jurnal Keperawatan, 12(2), 89-102. 